\title{
Medical ASSiSTANCE IN DYING: JOURNEY TO MEDICAL SELF-DETERMinATION
}

\author{
ROSE M. CARTER, Q.C. AND BRANDYN RODGERSON*
}

In 2016, the Supreme Court of Canada struck down the laws criminalizing medical assistance in dying (MAID) in Carter v. Canada (Attorney General). In this article, the authors discuss the historical prohibition on MAID in Canada, the important change in the law represented by Carter, and Bill C-14, the federal government's legislative response to the Supreme Court's verdict. The authors explain the new MAID regime created by Bill C-14 and discuss the various issues raised by the new legislation, including the possibly unconstitutional exclusion of patients not suffering from terminal conditions, problems of certainty in determining when death is "reasonably foreseeable," problems related to patients' mental capacity, and the need for effective data collection.

\section{TABLE OF CONTENTS}

I. INTRODUCTION . . . . . . . . . . . . . . . . . . . . . . . . . . . . . . 777

II. HiSTORY OF ASSISTED DEATH IN CANADA . . . . . . . . . . . . . . . . . 779

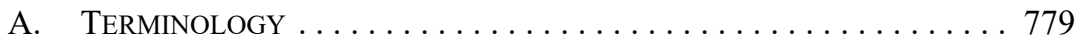

B. The History of Section 241 of the CRIMinal Code . . . . . . . 780

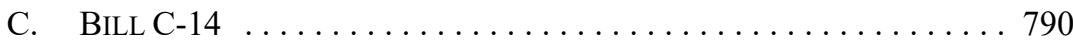

III. The CURRENT MAID REgIME $\ldots \ldots \ldots \ldots \ldots \ldots \ldots \ldots \ldots \ldots \ldots$

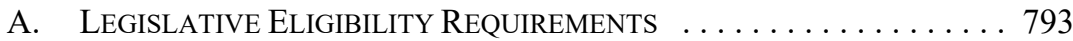

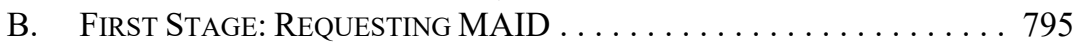

C. Second Stage: Assessments for Eligibility . . . . . . . . . 796

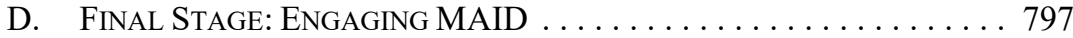

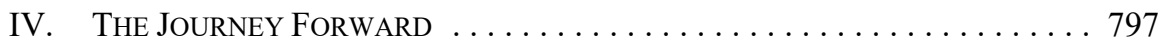

A. IsSUES of CONSTITUtionAlity $\ldots \ldots \ldots \ldots \ldots \ldots \ldots \ldots \ldots$

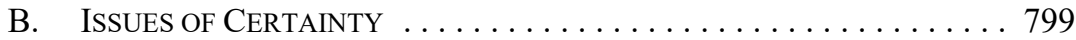

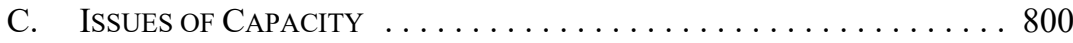

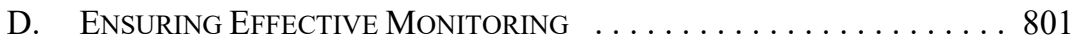

V. CONCLUSION .......................... 803

\section{INTRODUCTION}

The latest development on the journey to medical self-determination occurred in 2008 when Kay Carter, suffering from spinal stenosis - a debilitating condition that gradually compressed her spine, resulting in chronic pain — sought assistance to end her life. ${ }^{1}$ Due to the criminalization of assisted dying in Canada, Carter was left with the difficult decision to commit suicide or "live out her life as an "ironing board', lying flat in bed." Dissatisfied with her options within the confines of Canadian law, Carter travelled to Switzerland, where,

Rose M Carter, QC of Bennett Jones LLP is also an Adjunct Professor, Faculty of Medicine and Dentistry, University of Alberta, where she regularly teaches on medical legal issues. Brandyn Rodgerson is an articling student with the Alberta Court of Appeal and Bennett Jones LLP. The authors thank Natasha Birchall and Shaun Parsons for initial research they did while summer students at Bennett Jones LLP, as well as the library staff of Bennett Jones LLP for their assistance.

Carter v Canada (Attorney General), 2015 SCC 5, [2015] 1 SCR 331 at para 17 [Carter SCC]. Ibid. 
upon taking the prescribed dosage of sodium pentobarbital, she died within twenty minutes surrounded by her family. ${ }^{3}$

Not all Canadians wishing to engage with assistance in dying are able to travel to a jurisdiction where assisted death is legal, due to resource or medical constraints. One such individual was Gloria Taylor, who was diagnosed in 2009 with amyotrophic lateral sclerosis (ALS), a fatal neurodegenerative disease that causes progressive muscle weakness. ${ }^{4}$ ALS, a terminal illness with no effective treatments available, ${ }^{5}$ eventually causes the loss of use of hands and feet, along with the ability to walk, chew, swallow, and eventually to breathe. ${ }^{6}$ One of Taylor's greatest fears was that she would be rendered into a state where she would be completely reliant on others for her needs, spending the last years of her life "wracked with pain." "Unable to travel to Switzerland as Carter had, Taylor had to choose to commit suicide prematurely, or live her final years completely dependent on others. Dissatisfied with this choice, Taylor joined Lee Carter and Hollis Johnson, who assisted with Carter's final journey to Switzerland, and others ${ }^{8}$ as a plaintiff by Amended Notice of Civil Claim filed 15 August $2011 .{ }^{9}$ Together, the plaintiffs challenged the constitutionality of the Criminal Code $e^{10}$ provisions that prohibited assisted death — specifically sections $14,21,22,222$, and 241 thus providing the impetus for the Carter decision.

In 2012, the British Columbia Supreme Court allowed the plaintiffs' challenge on the basis that safeguards could be put in place to protect against risks of assisted death and granted Taylor a constitutional exemption to seek assisted death. ${ }^{11}$ Taylor's condition continued to deteriorate to the point that she required support for assistance with daily tasks and died while waiting for the appeal to be heard. ${ }^{12}$ The claim continued and was heard by the British Columbia Court of Appeal, which overturned the trial decision. ${ }^{13}$

In February 2015, the Supreme Court of Canada unanimously declared that the challenged provisions were unconstitutional, holding that the provisions infringed section 7 of the Canadian Charter of Rights and Freedoms ${ }^{14}$ in a manner that was overbroad and not in accordance with principles of fundamental justice. ${ }^{15}$ The Supreme Court held that sections 241(b) and 14 of the Criminal Code were

void insofar as they prohibit physician-assisted death for a competent adult person who (1) clearly consents to the termination of life; and (2) has a grievous and irremediable medical condition (including an illness,

Ibid.

Ibid at para 11 .

ALS Society of Canada, "What Is ALS?,” online: <https://www.als.ca/about-als/what-is-als/>.

Ibid.

Carter SCC, supra note 1 at paras 11-12.

The British Columbia Civil Liberties Association was also a plaintiff. They have a long-standing interest in patient rights and conduct advocacy and education in relation to end-of-life care: Carter v Canada (Attorney General), 2012 BCSC 886, 287 CCC (3d) 1 at para 45 [Carter BCSC].

Carter v Canada (Attorney General) (15 August 2011), Vancouver, BCCA S112688 (amended notice of civil claim).

RSC 1985, c C-46.

See Carter BCSC, supra note 8.

Carter SCC, supra note 1 at paras 12,32

See Carter v Canada (Attorney General), 2013 BCCA 435, 365 DLR (4th) 351 [Carter BCCA].

Part I of the Constitution Act, 1982, being Schedule B to the Canada Act 1982 (UK), 1982, c 11 [Charter].

Carter SCC, supra note 1 at paras 86, 126. 
disease or disability) that causes enduring suffering that is intolerable to the individual in the circumstances of his or her condition. ${ }^{16}$

The Supreme Court suspended this declaration of invalidity for one year ${ }^{17}$ during which Parliament and provincial legislatures could respond, should they choose, by enacting legislation consistent with the parameters of the Carter decision. ${ }^{18}$ The federal government responded by introducing Bill C-14, An Act to amend the Criminal Code and to make related amendments to other Acts (medical assistance in dying), ${ }^{19}$ in 2016 , which ultimately legalized medical assistance in dying (MAID).

The term "MAID," as deemed by the federal government, encapsulates the basis of this new legal medical practice. First, MAID encompasses two distinct types of acts: (1) where a medical professional directly administers a substance that causes the death of a patient (traditionally known as voluntary euthanasia); and (2) where a medical professional prescribes to a person a substance they can self-administer to cause their death (traditionally known as physician-assisted suicide). Second, assistance in dying is legal in a medical context only. Third, medical professionals other than physicians are able to provide medical assistance in dying: specifically, nurse practitioners. Fourth, the words "in dying" suggest that eligibility is limited to those whose death has become "reasonably foreseeable.".

This article addresses the history of assisted dying in Canadian law and how Canada moved from a prohibitive MAID regime to a permissive one. Following a summary of the history prior to Carter, this article will provide an overview of the 2016 legislation, the current procedure for accessing MAID, and developments in the journey forward.

\section{History of Assisted Death in CANADA}

\section{A. Terminology}

While the new medical practice has been deemed "MAID" by the federal government, ${ }^{21}$ common terminology also includes "euthanasia" and "physician-assisted suicide." According to the Canadian Medical Association (CMA) and surrounding medical literature, euthanasia is

knowingly and intentionally performing an act, with or without consent, that is explicitly intended to end another person's life and that includes the following elements: the subject has an incurable illness; the agent

\footnotetext{
Ibid at para 127.

Ibid at para 128 .

Ibid at para 126.

1st Sess, 42nd Parl, 2016 (assented to 17 June 2016), SC 2016, c 3 [Bill C-14].

Canada, Department of Justice, "Medical Assistance in Dying: Questions and Answers," online: $<$ www.justice.gc.ca/eng/cj-jp/ad-am/faq.html $>$.

21 The term "MAID" was endorsed by the Special Joint Committee over "physician-assisted dying" or "physician-hastened death" "as it reflects the reality that health care teams, consisting of nurses, pharmacists, and other health care professionals, are also involved in the process of assisted dying": Special Joint Committee on Physician-Assisted Dying, Medical Assistance in Dying: A Patient-Centred Approach (February 2016) at 10 (Chairs: Hon Kelvin Kenneth Ogilvie and Robert Oliphant). Although the legislative scheme in Quebec, released prior to the federal legislation, contains a slightly different definition of MAID ("medical aid in dying": Act Respecting End-of-Life Care, CQLR c S-32.0001, s 3(6) [End-of-Life Care Act]), MAID refers to the current Canadian practice.
} 
knows about the person's condition; commits the act with the primary intention of ending the life of that person; and the act is undertaken with empathy and compassion and without personal gain. ${ }^{22}$

Euthanasia itself is often categorized into active or passive, direct or indirect, voluntary or involuntary. ${ }^{23}$ In contrast, the CMA defines physician-assisted suicide as "a physician knowingly and intentionally provid[ing] a person with the knowledge or means or both required to end their own lives, including counseling about lethal doses of drugs, prescribing such lethal doses or supplying the drugs." 24

Several cases use the terms physician-assisted suicide, physician-assisted death, and physician-assisted dying interchangeably. ${ }^{25}$ In Carter BCSC, for instance, Justice Smith stated that

\footnotetext{
"[a]ssisted dying" and "assisted death" are generic terms used to describe both assisted suicide and voluntary euthanasia. "Physician-assisted death" $[\mathrm{PAD}]$ and "physician-assisted dying" are likewise generic terms that encompass physician-assisted suicide and voluntary euthanasia that is performed by a medical practitioner or a person acting under the direction of a medical practitioner. ${ }^{26}$
}

In this article, the authors use the generic term "assisted death" to encapsulate terminology used prior to the adoption of the term "MAID" and practices in other jurisdictions, and "MAID" to refer to the current Canadian practice, as described in the Criminal Code.

\section{B. The History of Section 241 of the CRIMINAL CoDE}

Section 241 of the Criminal Code has a long history extending back to the nineteenth century. Prior to the enactment of Canada's first criminal code it was an offence for a person to attempt to commit suicide or to counsel, aid, or abet another person to do so at common law. ${ }^{27}$ Historically, suicide ranked among the most severe crimes and was seen as a crime against the State and God. ${ }^{28}$ That law was codified in 1892: "Every one is guilty of an indictable offence and liable to imprisonment for life who counsels or procures any person to commit suicide, actually committed in consequence of such counselling or procurement, or who aids or abets any person in the commission of suicide." 29 The clause continued in force through successive reforms of the Criminal Code until 1953, when the provision was amended to read:

Canadian Medical Association, "CMA Policy: Euthanasia and Assisted Death (Update 2014)" at 1, online: $<$ https://www.cma.ca/Assets/assets-library/document/en/advocacy/EOL/cma-policy-euthanasiaassisted-death-updated-2014-e.pdf $>$. The authors rely on the CMA's definitions as medical or nurse practitioners are the people actually administering the substance causing death, and it is consequently wise to begin to recognize the necessary marriage between the medical and legal communities.

Douglas M Sawyer, John R Williams \& Frederick Lowy, "Canadian Physicians and Euthanasia: 2. Definitions and Distinctions" (1993) 148:9 CMAJ 1463 at 1463-64:

Active euthanasia is a positive act of commission, such as a lethal injection; passive euthanasia implies an act of omission, such as the withholding or withdrawal of treatment ... [d]irect euthanasia implies that the intended effect of an act, such as the ordering of a dose of narcotic, is to cause the patient's death; in indirect euthanasia ... the intention is to relieve suffering. Canadian Medical Association, supra note 22 at 2.

See OP v Canada (Attorney General), 2016 ONSC 3956, 361 CRR (2d) 1 at para 27 [OP]. Carter BCSC, supra note 8 at para 39.

Rodriguez v British Columbia (Attorney General), [1993] 3 WWR 553 at para 14 [Rodriguez BCCA]. William Blackstone, Commentaries on the Laws of England, Vol 4 (Oxford: Clarendon Press, 1769) at 189.

Criminal Code, 1892, 55 \& 56 Vict, c 29, s 237. 
Every one who

(a) counsels or procures a person to commit suicide, or

(b) aids or abets a person to commit suicide,

whether suicide ensues or not, is guilty of an indictable offence and is liable to imprisonment for fourteen years. ${ }^{30}$

At the same time, a patient's right to self-determination in medical decisions has long been recognized and protected by the law, extending from Justice Cardozo's — who served as the Chief Judge of the New York Court of Appeals — classic statement that "[e]very human being of adult years and sound mind has a right to determine what shall be done with his own body; and a surgeon who performs an operation without his patient's consent commits an assault, for which he is liable in damages." ${ }^{31}$ As stated by the Supreme Court of Canada in Carter:

The law has long protected patient autonomy in medical decision-making. In A.C. v. Manitoba (Director of Child \& Family Services), 2009 SCC 30, [2009] 2 S.C.R. 181, a majority of this Court, per Abella J. (the dissent not disagreeing on this point), endorsed the "tenacious relevance in our legal system of the principle that competent individuals are — and should be — free to make decisions about their bodily integrity" (para.

39). This right to "decide one's own fate" entitles adults to direct the course of their own medical care (para.

40): it is this principle that underlies the concept of "informed consent" and is protected by s. 7's guarantee of liberty and security of the person (para. 100; see also R. v. Parker (2000), 49 O.R. (3d) 481 (C.A.)). ${ }^{32}$

This respect for patients' autonomy is reflected in the evolution of the nature of the patient and physician relationship in the latter part of the twentieth century, as the relationship shifted from "an authoritarian or paternalistic model to a more egalitarian and participatory one." ${ }^{33}$ While the authoritative physician dictates treatment to their acquiescent patient, the egalitarian promotes understanding and patient control over their medical decisions. ${ }^{34}$

The doctrine of informed consent developed in the law as the primary means of protecting a patient's right to control their medical decisions. ${ }^{35}$ Broadly speaking, the doctrine of informed consent was introduced in the landmark decision of Reibl v. Hughes, where the plaintiff alleged he had not given informed consent to an endarterectomy that left him a hemiplegic. ${ }^{36}$ The Supreme Court imposed liability on the defendant surgeon for his failure to secure the plaintiff's informed consent, based on the tort of negligence. ${ }^{37}$ Thus, to ensure a patient's right to self-determination is exercised wisely, the doctrine of informed consent recognizes physicians' obligations to ensure their patients better understand their illness, alternative treatments available, and risks and benefits of those options. ${ }^{38}$ Underlying this doctrine is " $[\mathrm{t}]$ he right to determine what shall, or shall not, be done with one's own body, and to be free from non-consensual medical treatment."

Criminal Code, 2 \& 3 Eliz II, c 51, s 212.

Schloendorff $v$ Society of New York Hospital, 105 NE 92 at 93 (App Ct NY 1914).

Carter SCC, supra note 1 at para 67 [emphasis added].

Philip H Osborne, The Law of Torts, 5th ed (Toronto: Irwin Law, 2015) at 153.

Ibid at $153-54$

Ibid at 154 .

Reibl v Hughes, [1980] 2 SCR 880 [Reibl]. See also Hopp v Lepp, [1980] 2 SCR 192, where Chief Justice Laskin held there was a duty of disclosure. That is, the surgeon or physician was bound by a duty to provide information to his or her patient.

Reibl, ibid at 888-92, 925-29.

Osborne, supra note 33 at 154-55.

Fleming $v$ Reid (1991), 4 OR (3d) 74 at 85 (CA) [Fleming]. 
The latter half of the twentieth century saw a shift in the legal approach to end-of-life options. The federal government decriminalized attempted suicide in $1972^{40}$ and, soon after, the right for persons to refuse consent to medical intervention, or for a treatment to be withdrawn or discontinued despite harmful consequences that may follow, gained recognition. ${ }^{41}$ As Justice Robins stated in Malette v. Shulman:

\footnotetext{
The patient is free to decide, for instance, not to be operated on or not to undergo therapy or, by the same token, not to have a blood transfusion. If a doctor were to proceed in the face of a decision to reject the treatment, he would be civilly liable for his unauthorized conduct notwithstanding his justifiable belief that what he did was necessary to preserve the patient's life or health. ${ }^{42}$
}

The right to refuse treatment is also associated with two issues: the right to make decisions about one's own health and the right not to have one's body invaded. ${ }^{43}$

At the same time, the desire to achieve greater control over one's life and death was fueled by a greater understanding of how medical technology prolongs life and the desire to circumvent undue suffering that can accompany increased life spans. ${ }^{44}$ In light of this, the Law Reform Commission of Canada in 1982 carried out a critical examination of whether provisions relating to assisted death were adequate to deal with modern practices. ${ }^{45}$ In its report, Euthanasia, Aiding Suicide and Cessation of Treatment, the Commission stressed that the provisions of the Criminal Code relating to assisted death were outlined based on medical practices at that time. ${ }^{46}$ Furthermore, the Commission stressed that since the provisions had never received judicial interpretation, it was impossible to predict with any certainty what interpretation the courts might give to them in the modern medical context regarding decisions to cease life-supporting treatments. ${ }^{47}$ The Commission noted that while provisions were adequate to meet problems of the era for which they were conceived, amendments were needed to reflect changed realities. ${ }^{48}$ Even though the Commission explicitly acknowledged the need to protect principles of patient autonomy and self-determination, ${ }^{49}$ the Commission's report ultimately recommended that laws relating to assisted death remain in

Antoon A Leenaars et al, eds, Suicide in Canada (Toronto: University of Toronto Press, 1998) at 117 See e.g. Ciarlariello v Schacter, [1993] 2 SCR 119 at 135; Malette $v$ Shulman (1990), 72 OR (2d) 417 (CA) at 426 [Malette]; Nancy B c Hôtel-Dieu de Québec, [1992] RJQ 361 at 367 (CS); Fleming, supra note 39 at $85-86$.

Malette, ibid at 424. See also Reibl, supra note 36 at $894-95$.

Malette, ibid at $423-24$.

Parliamentary Information and Research Service, "Euthanasia and Assisted Suicide in Canada" (Background Paper) by Martha Bulter et al (Ottawa: Library of Parliament, 2013) at 1, online: <https:// lop.parl.ca/content/lop/ResearchPublications/2010-68-e.htm> [Parliamentary Information and Research Service, Background Paper].

45 Law Reform Commission of Canada, Euthanasia, Aiding Suicide and Cessation of Treatment, Report 20 (Ottawa: Minister of Supply and Services Canada, 1983) at 3 [Law Reform Commission of Canada, Report 20].

Ibid at 9 .

Ibid at 10 .

Ibid at 9 .

Ibid at 11-12. 
force. ${ }^{50}$ Consequently, in 1985 , the wording of section 241 was only slightly changed leaving the law that criminalized counselling or aiding suicide in force. ${ }^{51}$

\section{RODRIGUEZ}

In 1992, Sue Rodriguez, a 42-year-old mother suffering from ALS, began her fight to overturn the laws relating to assisted death. ${ }^{52}$ She applied to the British Columbia Supreme Court for an order that section 241(b) of the Criminal Code, which prohibits the giving of assistance to commit suicide, be declared invalid on the ground that it violated her rights under sections 7, 12, and 15(1) of the Charter and was therefore of no force. ${ }^{53}$ The Court dismissed Ms. Rodriguez's application, ${ }^{54}$ affirmed later by the majority of the British Columbia Court of Appeal. ${ }^{55}$

Justice Sopinka, writing for the majority of the Supreme Court of Canada, looked to the judgment in $R$. v. Morgentaler ${ }^{56}$ to determine what security of the person encompasses in this context. Justice Sopinka concluded that Morgentaler "can be seen to encompass a notion of personal autonomy involving, at the very least, control over one's bodily integrity free from state interference and freedom from state-imposed psychological and emotional stress." ${ }^{, 57}$ Since Rodriguez would inevitably spend the last days of her life wholly dependent on others and machines to perform bodily function, all while in increasing pain and discomfort, section 241(b) violated her section 7 Charter rights. ${ }^{58}$ At the time the Supreme Court of Canada heard Rodriguez, no Western democratic nation expressly permitted assisted suicide. ${ }^{59}$ In the Netherlands, although assisted suicide and voluntary active euthanasia were still officially illegal, prosecutions were not laid so long as there was compliance with medical guidelines. The Supreme Court of Canada pointed to critics of this Netherlands scheme who suggested that involuntary active euthanasia was on the rise and the country was headed down a

Ibid at 20-21. The Commission did, however, recommend that it be specified in the Criminal Code that a physician cannot be held criminally liable for: (1) undertaking appropriate palliative care to eliminate or reduce the suffering of an individual; (2) withdrawing treatment if it has become futile; or (3) discontinuing or refusing to initiate treatment "for an incompetent person, when that treatment is no longer therapeutically useful" and not in the patient's best interest (ibid at 22-28). Interestingly, in "Euthanasia, Aiding Suicide and Cessation of Treatment," (1982) Law Reform Commission of Canada Working Paper No 28, the Commission proposed the addition of the following subsection: "No person shall be prosecuted for an offence under the present section without the personal written authorization of the Attorney General" (ibid at 69). Chief Justice McEachern of the British Columbia Court of Appeal was of the view that the intention reflected in this proposed section was that "assisted suicide of terminally ill persons would be effectively decriminalized because it was expected that the Attorneys General would not give authorization to prosecute in such cases" (Rodriguez BCCA, supra note 27 at para 18). This recommendation was withdrawn in Report 20, published in 1983 (Law Reform Commission of Canada, supra note 45 at 21).

51 In 1985, the section was re-enacted as section 241, where the word "is" preceding the word "liable" was deleted and the words "a term of not more than" were added preceding the word "fourteen" (Criminal Code, supra note 10, s 241).

52 Also in 1992, Member of Parliament Svend Robinson, from Burnaby-Kingsway in British Columbia, introduced a private member's bill, Bill C-385, An Act to Amend the Criminal Code (Aiding Suicide), 3rd Sess, 34th Parl, 1992 [Bill C-385], "to allow for physician-assisted suicide upon the request of a terminally ill person." The closing of Parliament prevented the bill from coming forward for debate. Rodriguez v British Columbia (AG), 1992 CanLII 726 (BCSC).

Ibid.

Rodriguez BCCA, supra note 27.

[1988] 1 SCR 30 [Morgentaler].

Rodriguez v British Columbia (Attorney General), [1993] 3 SCR 519 at 587-88 [Rodriguez SCC].

Ibid at 588-89.

Ibid at 601-602. 
"slippery slope. ${ }^{160}$ From the perspective of Justice Sopinka, society simply did not oppose the right of the state to regulate or restrict the involvement of others in exercising suicidal acts. ${ }^{61}$ In the Supreme Court's view, since the law upheld the respect for life, discouraging individuals from committing suicide and given the concerns about abuse and the difficulty in creating appropriate safeguards, section 241(b) was not arbitrary or unfair and was reflective of fundamental values of Canadian society. ${ }^{62}$

The Supreme Court, though, was hardly in consensus over Rodriguez's case, issuing three distinct dissenting opinions. In her dissenting opinion, Justice McLachlin (as she then was) held that section 241(b) violates section 7 of the Charter.$^{63}$ Justice McLachlin concluded that it would be contrary to the principles of fundamental justice to deny Rodriguez the choice available to those who are physically able merely because of a fear of potential abuse.$^{64} \mathrm{In}$ contrast, Chief Justice Lamer's dissent focused on an analysis of section 15 of the Charter. Chief Justice Lamer wrote that section 241(b) treats physically disabled persons unequally, since those unable to commit suicide without assistance are unable to choose that option without committing a criminal offence, while those physically able to end their own lives may commit suicide without impunity. ${ }^{65}$ In his view, the concerns of a "slippery slope" could not justify a restriction on those that freely consent to suicide. ${ }^{66}$ Lastly, Justice Cory agreed with the reasons put forward by Chief Justice Lamer and Justice McLachlin ${ }^{67}$ stating:

The life of an individual must include dying. Dying is the final act in the drama of life. If, as I believe, dying is an integral part of living, then as a part of life it is entitled to the constitutional protection provided by s.

7 .... State prohibitions that would force a dreadful, painful death on a rational but incapacitated terminally ill patient are an affront to human dignity. ${ }^{68}$

Over the two decades following Rodriguez, legal battles relating to assisted death ensued. In 1998, for instance, Dr. Nancy Morrison stood trial on a charge of first-degree murder in the death of a terminally ill cancer patient, Paul Mills. ${ }^{69}$ By 1996, all possible treatment methods had failed Mills and, after family consultations, it was agreed that active life support would be discontinued. ${ }^{70}$ When Mills was taken off the ventilator he remained in substantial pain despite administration of pain control drugs. Morrison decided to administer nitroglycerine and then potassium chloride by syringe in lethal doses, consequently stopping his heart. ${ }^{71}$ Judge Randall of the Nova Scotia Provincial Court found that whatever Morrison's intentions when she administered the dosage, Mills could have died from either the enormous amount of painkillers he had received earlier or from natural causes because

$60 \quad$ Ibid at 603

Ibid at 585. The Supreme Court of Canada also noted that various medical associations were against decriminalizing assisted suicide at the time (ibid at 608).

Ibid at 608 .

Ibid at 624 .

Ibid at 626-28.

Ibid at 557.

Ibid at 566-69.

Ibid at 629 .

Ibid at 630. For further literature on Rodriguez, see Ian Dundas, "Rodriguez and Assisted Suicide in Canada" (1994) 32:4 Alta L Rev 811; Lisa Hobbs Birnie \& Sue Rodriguez, Uncommon Will: The Death and Life of Sue Rodriguez (Toronto: Macmillan, 1994).

$R v$ Morrison, [1998] NSJ No 75 (QL) (Prov Ct).

Ibid at para 3 .

Ibid at para 7 . 
an intravenous line delivering the various drugs was not working. ${ }^{72}$ Thus the case against Dr. Morrison was discharged. ${ }^{73}$

In 2002, Evelyn Martens was charged with aiding or abetting the suicide of Monique Charest of Duncan, British Columbia, and the suicide of Leyanne Burchell of Vancouver, British Columbia. ${ }^{74}$ Martens, an active member of the Right to Die Society of Canada, had sent literature to the two women and admitted she was with them when they died. ${ }^{75}$ The case turned on the question of whether she was there to provide comfort or to help or encourage the suicides. Ultimately, Martens was found not guilty. ${ }^{76}$ These are two examples of a wave of high-profile cases illustrating the difficulty of the legal issues surrounding end-of-life decisions leading up to Carter. ${ }^{77}$

During the 1990s and 2000s, numerous reports, consultations, and policies were released in response to the issue of assisted death. Soon after the Rodriguez decision was issued, the British Columbia Ministry of the Attorney General released guidelines for Crown Counsel with respect to charging individuals under these laws. Under the guidelines, Crown Counsel was to move forward with a prosecution "where there [was] a substantial likelihood of conviction and where prosecution [was] required in the public interest." ${ }^{, 78}$ According to these guidelines, "palliative care and withholding or withdrawing medical treatment [would] not be subject to criminal prosecution when ... administered according to accepted ethical medical standards.",79

In 1994, the Senate established a special committee to examine issues surrounding assisted death. In their report entitled Of Life and Death, ${ }^{80}$ the committee addressed a number of endof-life issues, including palliative care, pain control and sedation practices, withholding and withdrawal of life-sustaining treatment, and advance directives. The committee urged all levels of government and medical associations to create guidelines regarding palliative care and other end-of-life options, but the majority agreed that criminal prohibition on assisted

Ibid at paras 12-13.

Ibid at para 21. This decision was appealed to the Nova Scotia Supreme Court in 1998, where Justice Hamilton dismissed the appeal: $R v$ Morrison (1998), 174 NSR (2d) 201 (SC). The Public Prosecution did not appeal this decision (Parliamentary Information and Research Service, Background Paper, supra note 44 at 8 ).

$R v$ Martens, 2004 BCSC 1450, 2004 BCSC 1450 (CanLII).

Ibid.

Ibid.

See e.g. $R v$ Latimer (1997), 121 CCC (3d) 326 (SKQB) (accused convicted of second-degree murder in the asphyxiation death of his severely disabled 12-year-old daughter and sentenced to life in prison with no eligibility for parole for ten years); Sawatzky v Riverview Health Centre Inc (1998), 167 DLR (4th) 359 (MBQB) (disagreement between a physician, who attempted to initiate a DNR order, and the patient's wife, who resisted that order); $R$ v Genereux (1999), 44 OR (3d) 339 (CA) (physician pled guilty to two counts of aiding and abetting a patient to commit suicide after prescribing a lethal dose of a drug to two patients who had HIV but were not terminally ill); R c Houle, 2006 QCCS 319, 38 CR (6th) 242 (accused pled guilty to aiding and abetting the suicide of her 36-year-old son); R c Bergeron, 2006 QCCQ 10156, [2006] RJQ 3000 (accused was found guilty of aggravated assault for attempting to asphyxiate his wife, who was suffering from Friedreich's ataxia); $R v$ Fonteece, 2010 ONSC 2075, 2010 ONSC 2075 (CanLII) (accused pled guilty to criminal negligence for failing to seek medical help for his wife while being present during her suicide); R c Dufour, 2010 QCCA 2413, 2010 QCCA 2413 (CanLII) (accused was charged with counselling or aiding suicide after helping his uncle hang himself). See also Parliamentary Information and Research Service, Background Paper, supra note 44 at 7-11. British Columbia Ministry of the Attorney General, "Crown Counsel Policy Manual" by the Criminal Justice Branch (Victoria: AG, 15 March 2004) at 1.

Parliamentary Information and Research Service, Background Paper, supra note 44 at 14.

Senate, Special Senate Committee on Euthanasia and Assisted Suicide, Of Life and Death (June 1995) (Chair: Hon Joan B Neiman). 
death should remain intact, with less severe penalties imposed where the intention is merciful or compassionate. ${ }^{81}$ As a follow-up to this report, a Senate subcommittee was established in 1999 to monitor the recommendations made in Of Life and Death. Their final report released in 2000, entitled Quality End-of-Life Care: The Right of Every Canadian, ${ }^{82}$ acknowledged that end-of-life care was evolving far too slowly due to "[i]nadequate federal and provincial collaboration, deficient allocation of resources, and insufficient attention to the end-of-life health care needs of Canadians." ${ }^{, 3}$ Between 1991 and 2014, nine bills were brought to Parliament and the Senate which all sought in some form to decriminalize assisted death, ${ }^{84}$ all of which failed. ${ }^{85}$

\section{CARTER}

In 2012, nearly two decades after Rodriguez, Justice Smith of the British Columbia Supreme Court struck down sections 14 and $241(b) .{ }^{86}$ Noting that Rodriguez was a binding authority on certain portions of the plaintiffs' claims, ${ }^{87}$ she acknowledged that while the doctrine of stare decisis ensures predictability and certainty in the law, respect for the law will diminish if it fails to adapt to changing realities. ${ }^{88}$ While the facts were similar to those in Rodriguez, ${ }^{89}$ the social and legal realities had changed drastically. Socially, "palliative care practice including palliative sedation, end-of-life decision making, Canadian public opinion" on the topic, and experiences in other jurisdictions had all evolved since $1992 .{ }^{90}$ The Netherlands, Belgium, Luxembourg, Switzerland, and three US states permitted some form of assisted death, all of which had safeguards to ensure proper protocols and reporting requirements were satisfied. ${ }^{91}$ Justice Smith canvassed an array of Charter litigation over the

Parliamentary Information and Research Service, Background Paper, supra note 44 at 14 .

Senate, Subcommittee to Update OfLife and Death of the Standing Senate Committee on Social Affairs, Science and Technology, Quality End-of-Life Care: The Right of Every Canadian (June 2000) (Chair: Hon Sharon Carstairs).

Ibid at 3

Bill C-203, An Act to amend the Criminal Code (terminally ill persons), 3rd Sess, 34th Parl, 1991; Bill C-261, An Act to legalize the administration of euthanasia under certain conditions to persons who request it and who are suffering from and irremediable condition and respecting the withholding and cessation of treatment and to amend the Criminal Code, 3rd Sess, 34th Parl, 1991; Bill C-385, supra note 52; Bill C-215, An Act to amend the Criminal Code (aiding suicide), 1st Sess, 35th Parl, 1994; Bill S-13, An Act to amend the Criminal Code (protection of health care providers), 2nd Sess, 35th Parl, 1996; Bill S-29, An Act to amend the Criminal Code (protection of patients and health care providers), 1st Sess, 36th Parl, 1999; Bill C-407, An Act to amend the Criminal Code (right to die with dignity), 1st Sess, 38th Parl, 2005; Bill C-562, An Act to amend the Criminal Code (right to die with dignity), 2nd Sess, 39th Parl, 2008; Bill C-581, An Act to amend the Criminal Code (physician-assisted death), 2nd Sess, 41st Parl, 2014.

Parliamentary Information and Research Service, Background Paper, supra note 44 at 16-18. See also Jocelyn Downie, Dying Justice: A Case for Decriminalizing Euthanasia \& Assisted Suicide in Canada (Toronto: University of Toronto Press, 2004) for a discussion on how the principle of autonomy supports treating, in law, voluntary euthanasia and physician-assisted suicide the same as withholding and withdrawing of life-sustaining treatment.

Carter BCSC, supra note 8 at paras 1286-383. Intervenors included the Farewell Foundation for the Right to Die; Christian Legal Fellowship; Canadian Unitarian Council; Euthanasia Prevention Coalition; Euthanasia Prevention Coalition - British Columbia; and Ad Hoc Coalition of People with Disabilities Who Are Supportive of Physician-Assisted Dying. See also Carter v Canada (Attorney General), 2011 BCSC 1371, 2011 BCSC 1371 (CanLII) (where Justice Smith ruled on three applications with respect to the admission of evidence in this trial); Carter v Attorney General (Canada), 2011 BCSC 1866, 2011 BCSC 1866 (CanLII) (where the request by CBC to record the trial proceedings for television broadcast was denied).

Carter BCSC, ibid at para 12 .

Ibid at para 900 .

Ibid at para 939.

Ibid at para 942 .

Ibid at paras 9, 683-85. 
prior two decades, recognizing that "additional principles of fundamental justice [had] been recognized and defined since Rodriguez." ${ }^{.92}$ It was thus appropriate to revisit the constitutionality of section 241(b) even though it had been upheld on certain principles of fundamental justice in Rodriguez. ${ }^{93}$ Since Rodriguez did not decide whether section $241(b)$ violates equality rights of physically disabled people, Justice Smith concluded it was also open to the British Columbia Supreme Court to assess the plaintiffs' section 15 claim. ${ }^{94}$

Turning her attention to the Charter, Justice Smith held that the provisions unjustifiably infringed the section 15 equality rights of Gloria Taylor and the section 7 rights to life, liberty, and security of the person of Gloria Taylor, Lee Carter, and Hollis Johnson. ${ }^{95}$ With respect to the latter, Justice Smith held that infringement on plaintiffs' rights was not in accordance with principles of fundamental justice, ${ }^{96}$ nor could they be saved under section 1 of the Charter. ${ }^{97}$ The evidence supported the conclusion that assisted death already occurs in Canada to an unknown extent, and moving to a system of regulated assisted death would eliminate such deaths and enhance the likelihood that proper safeguards could be established. ${ }^{98}$ Under section 52 of the Constitution, the provisions were declared invalid, but the operation of that declaration was suspended for one year, during which time Parliament could take whatever steps it saw fit. ${ }^{99}$ In the interim, Justice Smith granted Taylor the right to seek assisted death under a number of conditions. ${ }^{100}$

The Canadian federal government announced they would appeal the British Columbia Supreme Court's ruling that overturned Canada's assisted death laws. ${ }^{101}$ While announcing their plans to appeal, the Canadian Minister of Justice also indicated that the government would seek "a stay of all aspects of the lower court decision," including a stay of Taylor's exemption. ${ }^{102}$ On 10 August 2012, though, the British Columbia Court of Appeal's Justice Prowse denied the request for a stay of Taylor's exemption, saying to deny her the death of her choosing would cause her "irreparable harm." 103

Ibid at para 983 .

Ibid at para 985 .

Ibid at paras $987-88$.

Ibid at paras $1161,1325-30,1371$.

Ibid at paras $1371,1377-78$.

Ibid at paras 1379-83.

Ibid at para 1370 .

Ibid at paras 2, 19, 1399, 1411.

Ibid at para 1411 .

Patient's Rights Council, "Canadian Government Appeals Sweeping Assisted-Suicide Ruling” (2012)

26:4 Update 5 at 5, online: <www.patientsrightscouncil.org/site/wp-content/uploads/2012/09/ Update_2012_4.pdf>.

102 Department of Justice, News Release, "Response of The Attorney General of Canada to The British Columbia Supreme Court Decision On Assisted Suicide” (13 July 2012), online: <https://www. canada.ca/en/news/archive/2012/07/response-attorney-general-canada-british-columbia-supreme-courtdecision-assisted-suicide.html $>$.

103 Carter v Canada (Attorney General), 2012 BCCA 336, 291 CCC (3d) 373 at paras 40-45. On 17 August, the Minister announced that the government would appeal the stay denial: Department of Justice, News Release, "The Attorney General of Canada to Appeal the Refusal by a Judge of the British Columbia Court of Appeal to Stay the Constitutional Exemption Granted In the Carter Case" (17 August 2012), online: $<$ https://www.canada.ca/en/news/archive/2012/08/attorney-general-canada-appeal-refusal -judge-british-columbia-court-appeal-stay-constitutional-exemption-granted-carter-case.html $>$. "Taylor passed away prior to the appeal of this matter, without accessing the exemption" (Carter SCC, supra note 1 at para 32 ). 
In 2013, the British Columbia Court of Appeal allowed the appeal of the trial decision in Carter. ${ }^{104}$ Justice Newbury, writing for the majority, stressed the importance of stare decisis in Canadian law. In her view, the trial judge was bound to find that Rodriguez had authoritatively decided the plaintiffs' case. ${ }^{105}$ In the event that the Supreme Court of Canada were to review Rodriguez, however, the majority went on to suggest that consideration should be given to the remedy of a "constitutional exemption" in favour of persons "who are clear-minded, supported in their life expectancy by medical opinion, rational and without outside influence." 106

Given the importance of the issue and its universal application to all individuals, in combination with the judicial debate regarding stare decisis and Rodriguez, the Supreme Court of Canada granted leave to appeal the decision of the British Columbia Court of Appeal. ${ }^{107}$ On 6 February 2015, the Supreme Court of Canada held in a unanimous decision that sections 241(b) and 14 of the Criminal Code unjustifiably infringe section 7 of the Charter. The provisions were found to be of no force to the extent that they prohibit assisted death for a competent adult person who (1) "clearly consents to the termination of life"; and (2) "has a grievous and irremediable medical condition (including an illness, disease or disability) that causes enduring suffering that is intolerable to the individual in the circumstances of his or her condition." 108

At the outset, it was clear that the Supreme Court of Canada was more alert to the plaintiffs' concerns than it had been in Rodriguez, opening with the following statement:

It is a crime in Canada to assist another person in ending her own life. As a result, people who are grievously and irremediably ill cannot seek a physician's assistance in dying and may be condemned to a life of severe and intolerable suffering. A person facing this prospect has two options: she can take her own life

Intervenors included Alliance of People With Disabilities Who Are Supportive of Legal Assisted Dying Society; Canadian Unitarian Council; Farewell Foundation for the Right to Die; Christian Legal Fellowship; Evangelical Fellowship of Canada; Euthanasia Prevention Coalition and the Euthanasia Prevention Coalition - British Columbia; Council of Canadians with Disabilities; and Canadian Association for Community Living. See Carter v Canada (Attorney General), 2012 BCCA 502, 272 CRR (2d) 255, which addressed eight applications for leave to intervene in the appeal.

Carter BCCA, supra note 13 at paras 263-71, 324. Chief Justice Finch, in his dissenting judgment, agreed with Justice Smith that although the Supreme Court of Canada considered section 7 of the Charter in Rodriguez, the analysis focused on security of the person and not on the deprivation of life that can result from a premature death or a loss of quality of life at the end of an individual's life (ibid at paras 61-69, 88-89). Thus, he would have dismissed the appeal against her section 7 order (ibid at paras 171, 179). Chief Justice Finch agreed with the majority, though, that Justice Smith was bound by Rodriguez on the basis of the full section 1 analysis conducted by the Supreme Court of Canada on the assumed section 15 analysis, and would have allowed the appeal on Justice Smith's section 15 order (ibid at paras 106-108).

106 Carter BCCA, ibid at paras 333-34. The remedy of a constitutional exemption had been favoured by a minority of the Supreme Court of Canada in Rodriguez in the context of a conclusion that the law infringed the Charter rights of Rodriguez: Rodriguez SCC, supra note 57 at 579.

107 Intervenors included the Attorney General of Ontario; Attorney General of Quebec; Council of Canadians With Disabilities; Canadian Association for Community Living; Christian Legal Fellowship; Canadian HIV/AIDS Legal Network; HIV \& AIDS Legal Clinic Ontario; Association for Reformed Political Action Canada; Physicians' Alliance Against Euthanasia; Evangelical Fellowship of Canada; Christian Medical and Dental Society of Canada; Canadian Federation of Catholic Physicians' Societies; Dying With Dignity; Canadian Medical Association; Catholic Health Alliance of Canada; Criminal Lawyers' Association(Ontario); Farewell Foundation for the Right to Die; Association québécoise pour le droit de mourir dans la dignité; Canadian Civil Liberties Association; Catholic Civil Rights League; Faith and Freedom Alliance; Protection of Conscience Project; Alliance of People With Disabilities Who Are Supportive of Legal Assisted Dying Society; Canadian Unitarian Council; and Euthanasia Prevention Coalition. 
prematurely, often by violent or dangerous means, or she can suffer until she dies from natural causes. The choice is cruel. ${ }^{109}$

The Supreme Court did not end there, referencing affidavit evidence from persons such as Taylor, who did not want her "life to end violently ... [, dying] slowly, piece by piece ... wracked with pain." 110 The Supreme Court referenced other witnesses who described the progression of their degenerative illnesses, agony of treatment, fear of gruesome deaths, ${ }^{111}$ and testimonials from witnesses who had considered committing suicide by "blow[ing their] head off," among other means, but often found it too repugnant. ${ }^{112}$

Before conducting a Charter analysis, the Supreme Court addressed the issue of stare decisis and whether Rodriguez bound the trial judge. They held that, while stare decisis is fundamental to our legal system to provide certainty and order, it "is not a straitjacket that condemns the law to stasis. Trial courts may reconsider settled rulings of higher courts in two situations: (1) where a new legal issue is raised; and (2) where there is a change in the circumstances or evidence that "fundamentally shifts the parameters of the debate." 113 In the Supreme Court's view, both conditions were satisfied in this case. ${ }^{114}$

Addressing section 7 of the Charter, the Supreme Court found that it is rooted in respect for the sanctity of life, but "also encompasses life, liberty and security of the person during the passage to death" and, as such, an individual's choice about the end of their life warrants respect in an effort to protect "individual autonomy and dignity." "115 Additionally, the Supreme Court found that by leaving people such as Taylor to endure intolerable suffering, the law violates their security of the person. ${ }^{116}$ Although the law was not arbitrary, in the sense that the prohibition achieved the object of the law "to protect the vulnerable from ending their life in times of weakness," 117 the Supreme Court found the law to be overbroad as it extended to competent, fully informed, and non-vulnerable adult patients who were prevented from ending their life with dignity. ${ }^{118}$ Having concluded that the provisions violated section 7 of the Charter, the Supreme Court supported Justice Smith's finding that section 1 could not save the provisions. ${ }^{119}$ It did not address whether the prohibition also violated section 15 of the Charter. ${ }^{120}$ The Supreme Court declared that the appropriate remedy was not to grant a free-standing constitutional exemption, but rather to issue a declaration of invalidity and suspend it for one year, during which time Parliament and provincial legislatures could craft a legislative response. ${ }^{121}$

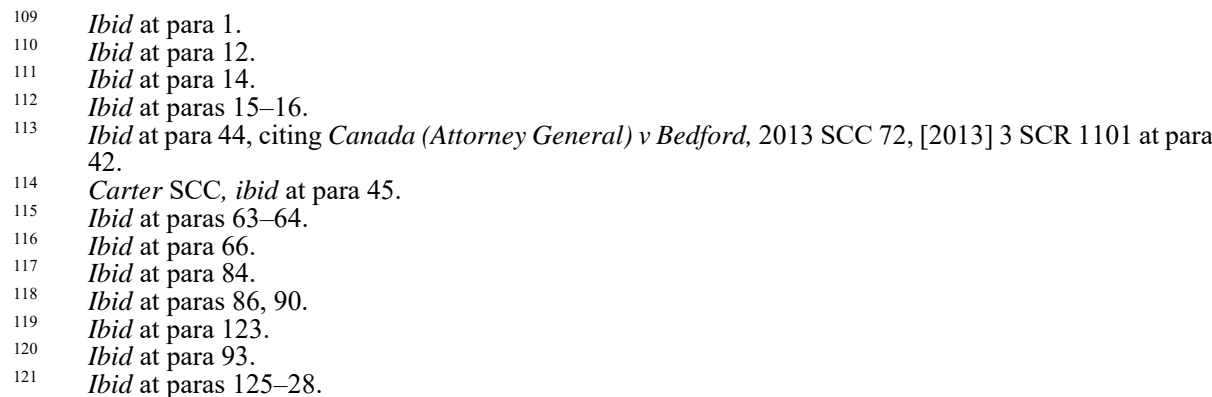




\section{BILL C-14}

As the Supreme Court of Canada noted in Carter, it was "in the hands of the physicians' colleges, Parliament, and the provincial legislatures" "122 to establish, if they chose, clear rules around who is eligible to seek assisted death and what safeguards must be in place to protect vulnerable individuals, and to create a monitoring regime to ensure consistency across Canada, accountability, transparency, and public trust. ${ }^{123}$ In 2015, approximately four months prior to expiration of the suspension of the declaration of the Supreme Court that sections 14 and 241(b) were of no force, the Canadian federal election occurred and the Attorney General of Canada applied to the Supreme Court of Canada for a six month extension of the Supreme Court's Carter decision. ${ }^{124}$

The appellants, opposing the Attorney General's application, argued that should an extension of the suspension be granted, the Supreme Court should grant constitutional exemptions for individuals who wished to seek assistance in ending their life during the extension period. ${ }^{125}$ The majority of the Supreme Court noted that " $[\mathrm{t}] \mathrm{o}$ suspend a declaration of the constitutional invalidity of a law is an extraordinary step," since the continuation of a constitutionally invalid law is a continuation of the violation of Canadian citizens' constitutional rights. ${ }^{126}$ Nonetheless, since Parliament was dissolved in August 2015 for the federal election and did not officially resume until December 2015, the Supreme Court held that the four month delay justified granting the extension, but only for four months. ${ }^{127}$

Secondly, the Supreme Court held that the Quebec legislation regulating end-of-life assistance, An Act respecting end-of-life care, ${ }^{128}$ would be exempted from any suspension granted. ${ }^{129}$ This legislation came into force in December $2015^{130}$ and allowed a person to request "medical aid in dying" — which consists of a physician administering medication to patients at their request, in order to relieve their suffering by hastening death ${ }^{131}$ - in accordance with guidelines set out in the legislation. ${ }^{132}$ Regarding the coexistence of the Quebec assisted dying legislation and the federal provisions, the majority of the Supreme Court of Canada in Carter refused to explicitly express whether the Quebec assisted dying legislation is valid, aside from a comment in the first Carter decision from the Supreme Court of Canada recognizing the concurrent jurisdiction over health between federal and

Ibid at para 132 .

Ibid.

Carter v Canada (Attorney General), 2016 SCC 4, [2016] 1 SCR 13 at para 1 [Carter SCC-2].

Ibid.

Ibid at para 2.

Ibid.

End-of-Life Care Act, supra note 21. See Michelle Giroux, "Informing the Future of End-of-Life Care in Canada: Lessons From the Quebec Legislative Experience" (2016) 39:2 Dal LJ 431.

Carter SCC-2, supra note 124 at paras 3-4.

OC 1165-2015, (2015) GOQ II, 3443 at 3444. The second paragraph of section 52 and sections 57 and 58 did not come into force until June 2016: OC 441-2016, (2016) GOQ II, 2235 at 2235.

End-of-Life Care Act, supra note 21, s 3(6).

That is, where a patient is insured as per the Health Insurance Act, CQLR, c A-29, is of full age and capable of giving consent, is "at the end of life," has a serious and incurable illness, is in an advanced state of irreversible decline in capability, and is experiencing constant and unbearable physical or psychological suffering which cannot be relieved in a manner the patient deems tolerable (End-of-Life Care Act, ibid, s 26). The form must be signed in the presence of and countersigned by a health or social services professional (ibid). See also Quebec, Ministry of Health and Social Services, "Medical Aid in Dying: Description," online: <www.sante.gouv.qc.ca/en/programmes-et-mesures-daide/aide-medicale-amourir/>. 
provincial governments. ${ }^{133}$ This legislation remains in force in conjunction with the new federal legislation, described in depth below. ${ }^{134}$

Finally, the Supreme Court held that during the extension period a constitutional exemption was granted so those wishing to seek assistance from a physician in accordance with the criteria as set out in Carter may apply to the superior court of their jurisdiction for an order. ${ }^{135}$ Following the return of Parliament, the federal government established the Special Joint Committee on Physician-Assisted Dying, whose purpose was

to review the report of the External Panel on Options for a Legislative Response to [Carter] and other recent relevant consultation activities and studies, to consult with Canadians, experts and stakeholders, and make recommendations on the framework of a federal response on physician-assisted dying that respects the Constitution, the [Charter], and the priorities of Canadians. ${ }^{136}$

With the Supreme Court of Canada granting a constitutional exemption, the journey continued, with those seeking assisted death bringing applications before superior courts across the country. The first case heard by a provincial common law superior court was H.S. (Re), where an ALS-diagnosed patient had been determined to have six months to live. ${ }^{137}$ While S. once had a very active life with many hobbies and a rewarding career, her condition had deteriorated to the point where she was almost completely paralyzed and unable to speak. ${ }^{138}$ In accordance with the criteria established by the Supreme Court of Canada in Carter, Justice Martin found: S. was mentally alert and not depressed, based on physician statements attached to her affidavit in which she clearly stated she consented; she had explored various options and considered her choice for a prolonged period; and she was suffering from a "grievous and irremediable medical condition" that was causing "enduring and intolerable suffering," which could not be alleviated by any treatment acceptable to her. ${ }^{139}$ Therefore, she permitted S. to seek assisted death. ${ }^{140}$

Carter SCC-2, supra note 124 at para 4; Carter SCC, supra note 1 ("[t]his suggests that aspects of physician-assisted dying may be the subject of valid legislation by both levels of government, depending on the circumstances and focus of the legislation" at para 53).

The Fédération médicale étudiante du Québec states that "[a]s the harmonization of the two legislations pends, the Collège des Médecins du Québec (CMQ) recommends its members to follow Quebec law": Fédération médicale étudiante du Québec, "Medical Assistance in Dying" by Philippe Simard, online: $<$ www.fmeq.ca/wp-content/uploads/2017/01/Medical-Assistance-in-Dying.pdf $>$. The Government of Quebec's website also acknowledged differences between the federal and provincial provisions but does not specifically say anything about how the differences should be reconciled: Quebec Ministry of Health and Social Services, "Medical Aid in Dying: Procedure," online: <www.sante.gouv.qc.ca/en/ programmes-et-mesures-daide/aide-medicale-a-mourir/demarche/>. However, the Collège des médecins du Québec recently reviewed their Guide sur l'aide médicale à mourir to take note of the federal modifications to the Criminal Code: see Collège des médecins du Québec, Nouveau guide sur l'aide médicale à mourir, online: $<$ www.cmq.org/publications-pdf/p-1-2017-11-20-fr-aide-medicale-a-mourir2017.pdf? $\mathrm{t}=1511481600024>$. The first constitutional challenge to the Quebec legislation went to the Quebec Court of Appeal: Québec (Procureur général) c D’Amico, 2015 QCCA 2138, 2015 QCCA 2138 (CanLII), aff'g D’Amico c Québec (Procureure générale), 2015 QCCS 5556, 2015 QCCS 5556 (CanLII). Carter SCC-2, supra note 124 at para 6.

136 See Special Joint Committee on Physician-Assisted Dying, supra note 21 at 2; House of Commons, Journals, 42nd Parl, 1st Sess, No 7 (11 December 2015) at 50; Senate, Journals of the Senate, 42nd Parl, 1 st Sess, No 6 (11 December 2015) at 56. HS (Re), 2016 ABQB 121, 394 DLR (4th) 664 at para 10.

Ibid.

Ibid at paras 95, 104, 109-17.

$\mathrm{S}$. was forced to travel to British Columbia to receive a lethal injection after being unable to find a physician in her hometown willing to help. See Tom Blackwell, "Alberta's Odd Road to Assisted Death: MD Helping Lead Its Implementation Opposed to It," National Post (4 March 2016), online: <national post.com/news/canada/albertas-odd-road-to-assisted-death-md-overseeing-its-implementation-opposesit/>. See also AB v Canada (Attorney General), 2016 ONSC 1912, 129 OR (3d) 749 (advanced-stage 
Another notable case was in E.F., ${ }^{141}$ where the Alberta Court of Appeal commented on two issues: (1) does the constitutional exemption in Carter apply only to applicants suffering from terminal illness?; and (2) are individuals suffering from psychiatric conditions excluded from the constitutional exemption? ${ }^{142}$ The Attorney Generals of Canada and British Columbia, the appellants, also argued that medical evidence presented to the motions judge was insufficient to conclude that E.F.'s psychiatric condition, diagnosed as "severe conversion disorder," was "irremediable." 143 Regarding the latter issue, the Court was satisfied that the motions judge made her conclusion based on three physicians' opinions, one of whom had been E.F.'s attending physician for 28 years. ${ }^{144}$ While it may be desirable to have direct psychiatric evidence, the Court held that an absolute evidentiary requirement could impose an undue burden on potential applicants. ${ }^{145}$

In terms of the first issue on appeal in E.F., the Alberta Court of Appeal stated that nowhere in Carter is the right to assisted dying expressly limited only to those who are terminally ill or near the end of life. ${ }^{146}$ At the time of her application for MAID, E.F.'s quality of life had deteriorated to the point of "non-existen[ce]."147 Canada accepted that a dictionary definition of a "'grievous and irremediable' medical condition could include conditions that are not life-threatening or terminal." Canadians face at the end of their life that the Supreme Court of Canada presented in the first paragraph of Carter, ${ }^{149}$ the Alberta Court of Appeal held that this cruelty exists whether the illness is classified as terminal or not. ${ }^{150}$

Relating to the second issue on appeal, even though E.F. suffered from a psychiatric condition, her mental competence and whether she was voluntarily consenting were never

aggressive lymphoma); Patient v Attorney General of Canada, 2016 MBQB 63, 396 DLR (4th) 351 (two terminal diseases, one of which causes progressive loss of function and death); $A B \vee$ Canada (Attorney General), 2017 ONSC 3759, 2017 ONSC 3759 (CanLII) [AB] (rare form of a progressive, permanent, and irreversible osteoarthritis); $A A(R e), 2016$ BCSC 570, 2016 BCSC 570 (CanLII) (multiple sclerosis); $C D \vee$ Canada (Attorney General), 2016 ONSC 2431, 2016 ONSC 2431 (CanLII) (stage 4 metastatic breast cancer that had spread to her lungs, limbs, bones, and lymphatic system); XY V Canada (Attorney General), 2016 ONSC 2585, 2016 CarswellOnt 9540 (ALS); EF v Canada (Attorney General), 2016 ONSC 2790, 130 OR (3d) 711 (renal cancer returned, metastasized, and spread to her bones, spine, skull, lungs, pancreas, and adrenal glands, and the pain was exacerbated by a broken pelvis); Tuckwell (Re), 2016 ABQB 302, 401 DLR (4th) 335 (ALS); Canada (Attorney General) v EF, 2016 ABCA 155, 403 DLR (4th) 461 [EF] (severe conversion disorder); Patient $0518 v$ RHA 0518, 2016 SKQB 176, 2016 SKQB 176 (CanLII) (ALS and metastatic bone disease); MNv Canada (Attorney General), 2016 ONSC 3346, 2016 ONSC 3346 (CanLII) (terminal ampullary cancer which has metastasized to the liver and ovaries); IJ v Canada (Attorney General), 2016 ONSC 3380, 131 OR (3d) 789 (not terminal, suffered from spinal stenosis, discogenic disease, neurogenic claudication, lumbosacral facet osetoarthropathy, spondylolisthesis, rotoscoliosis, major kyphosis, and sacroiliac joint complex pain disorder); WBB (Re), 2016 BCSC 1005, 2016 BCSC 1005 (CanLII) (ALS); HH (Re), 2016 BCSC 971, 2016 BCSC 971 (CanLII) (mitochondrial encephalomyopathy, lactic acidosis, and stroke-like episodes, or "MELAS"); Barnes (Re), 2016 NLTD(G) 106, 361 CRR (2d) 250 (publication ban); OP, supra note 25 (Stage 4 glioblastoma multiforme, an incurable brain cancer in the left temporal lobe). EF, ibid.

Ibid at para 11 .

Ibid at paras 7, 12 .

Ibid at paras $62-66$.

Ibid at para 67.

Ibid at para 28 .

Ibid at para 7.

Ibid at para 33.

Carter SCC, supra note 1 ("[a] person facing this prospect has two options: she can take her own life prematurely, often by violent or dangerous means, or she can suffer until she dies from natural causes. The choice is cruel" at para 1).

$E F$, supra note 140 at para 37. 
in dispute. ${ }^{151}$ Although federal legislation had not yet been implemented at the time of the decision, the Alberta Court of Appeal noted that the Supreme Court of Canada in Carter considered the specific issue of whether those suffering from psychiatric conditions should be excluded from the declaration of invalidity, citing:

\begin{abstract}
Based on the evidence regarding assessment processes in comparable end-of-life medical decision-making in Canada, the trial judge concluded that vulnerability can be assessed on an individual basis, using the procedures that physicians apply in their assessment of informed consent and decisional capacity in the context of medical decision-making more generally. Concerns about decisional capacity and vulnerability arise in all end-of-life medical decision-making. Logically speaking, there is no reason to think that the injured, ill, and disabled who have the option to refuse or to request withdrawal of lifesaving or life-sustaining treatment, or who seek palliative sedation, are less vulnerable or less susceptible to biased decision-making than those who might seek more active assistance in dying. The risks that Canada describes are already part and parcel of our medical system. ${ }^{152}$
\end{abstract}

The Alberta Court of Appeal held that the Supreme Court of Canada was faced with the issue of whether psychiatric conditions should be excluded from the declaration of invalidity but declined to make that exclusion "as part of its carefully crafted criteria." ${ }^{153}$ E.F.'s request for MAID was accordingly granted. ${ }^{154}$

Similarly, in I.J., although the applicant did not have an imminently terminal condition, he suffered from "horrific" ailments. ${ }^{155}$ The applicant's condition was causing excruciating pain, sleep apnea, digestive issues, mental anguish, and difficulty breathing, swallowing, and speaking. ${ }^{156}$ In agreement with E.F., Justice Perell of the Ontario Supreme Court stated there is "no requirement ... that a medical condition be terminal or life-threatening" and this is therefore not determinative. ${ }^{157}$ Instead, it is merely one factor considered in the unique circumstances of each applicant seeking MAID. ${ }^{158}$

\title{
III. The CuRrent MAID Regime
}

\section{A. LegisLative ELIGIBILITY REQUIREMENTS}

In April 2016, Federal Justice Minister Jody Wilson-Raybould tabled Bill C-14, An Act to amend the Criminal Code and to make related amendments to other Acts (medical assistance in dying), in Parliament. ${ }^{159}$ After a month of debate, ${ }^{160}$ Bill C-14 passed a second

Ibid at para 7.

Carter SCC, supra note 1 at para 115, cited in EF, ibid at para 55.

EF, ibid at para 59.

Ibid at para 69.

$I J$, supra note 140 at para 4 . The applicant suffered from spinal stenosis, discogenic disease, neurogenic claudication, lumbosacral facet osetoarthropathy, spondylolisthesis, rotoscoliosis, major kyphosis, and sacroiliac joint complex pain disorder (ibid at para 5).

Ibid at paras 5-6.

Ibid at para 19.

Ibid at paras 20-22.

Bill C-14, supra note 19.

See e.g. House of Commons Debates, 42nd Parl, 1st Sess, No 46 (2 May 2016) at 2733 (Joël Godin):

Do my colleagues know that a person other than nurse practitioners and doctors can go around with the famous drug that ends life?... That is dangerous. People will be able to walk the streets with a drug that kills. We must also protect our seniors. They are vulnerable people. Heirs, insurance policies, caregivers, and families can take advantage of seniors. Let us protect our seniors. Let us be restrictive and put safeguards in place to impose as many limits as possible. 
and third reading in Parliament in May 2016. ${ }^{161}$ Also in May 2016, its first reading occurred in the Senate. ${ }^{162}$ The Senate sent Bill C-14 back to Parliament, along with seven amendments to the proposed legislation. While senators rarely alter government legislation to such an extent, many senators expressed concern over the constitutionality of Bill C-14, particularly the government's decision to restrict MAID to individuals whose natural death is "reasonably foreseeable." ${ }^{163}$ Parliament adopted many proposed amendments but stood firm on Bill C14 's central premise: that only those with a "reasonably foreseeable" death should qualify for MAID. On 17 June 2016, Bill C-14 became the law of the land. ${ }^{164}$

In establishing the new legislative scheme, the federal government sought to accomplish the following objectives:

- Recognize personal autonomy and dignity

- Recognize inherent and equal value of every life

- Include robust safeguards to protect vulnerable persons and guard against errors or abuse

- Set out eligibility for competent adults where death is reasonably foreseeable and who are suffering intolerably

- Balance different interests, including personal autonomy toward the end of life and the protection of vulnerable persons

- Encourage consistent approach across Canada. ${ }^{165}$

In an effort to balance the same competing interests the courts had considered for years, that is, respect for autonomy and protection of the vulnerable, the government's legislative scheme amended the criminal law to permit medical professionals to provide MAID,${ }^{166}$ but with restrictive legislative requirements.

To be eligible for MAID in Canada, an individual must:

- be "eligible ... for health services funded by a government in Canada"; ${ }^{167}$

Parliament of Canada, "House Government Bill C-14," online: Legisinfo <www.parl.ca/LegisInfo/Bill Details.aspx $?$ Bill $=\mathrm{c} 14 \&$ Language $=\mathrm{e} \&$ Mode $=1 \&$ Parl $=42 \&$ Sess $=1>$.

Ibid.

John Paul Tasker, "Physician-Assisted Dying Bill Passes Senate 64-12, Sent Back to House," CBC News (16 June 2016), online: <www.cbc.ca/news/politics/senate-amendments-c14-1.3636488>. A full PDF document of the proposed amendments may be found online: Parliament of Canada $<$ www.sen.parl.gc. $\mathrm{ca} /$ portal/c14-amendments/HOCAmendment-E.pdf $>$.

Bill C-14, supra note 19.

Department of Justice, "Medical Assistance in Dying: Overview of Federal Government Response" at 4, online: $<w w w . j u s t i c e . g c . c a / e n g / c j-j p / a d-a m / d o c s / o v e r v i e w . p d f>$. These objectives are reflected in the preamble of Bill C-14, ibid.

The government chose to add an exemption to protect medical practitioners and nurse practitioners from being prosecuted under section 241(b): Criminal Code, supra note 10, ss 241(2)-(7). That is, the government left section 241(b) in place to prevent anyone other than a medical professional from carrying out any act of euthanasia or assisted suicide.

Criminal Code, ibid, s 241.2(1)(a). 
- be "at least 18 years of age and capable of making decisions with respect to their health"; 168

- "have a grievous and irremediable medical condition," meaning "they have a serious and incurable illness," "they are in an advanced state of irreversible decline in capability," they are in "physical or psychological suffering that is intolerable to them and that cannot be relieved under conditions they consider acceptable," and their "death has become reasonably foreseeable"; ${ }^{169}$

- "have made a voluntary request for [MAID] that ... was not made as a result of external pressure"; ${ }^{170}$ and

- "give informed consent to receive [MAID]," meaning that the patient must be informed of their diagnosis and prognosis, reasonable alternative treatments available and their associated common risks, including palliative care, the fact they can rescind their request for MAID at any time, and the exact nature of the MAID procedure and the consequences of receiving or not receiving MAID. ${ }^{171}$

That is, any person who has not reached the age of majority, who lacks the necessary capacity due to a disability or otherwise, or whose death is not reasonably foreseeable does not fall under the scope of the new legislative scheme.

\section{B. First StAge: ReQuesting MAID}

After a person speaks with their medical or nurse practitioner about their end-of-life care options, believes they meet the above requirements, and decides to explore MAID, that person must make a formal request for a practitioner to prescribe a substance causing death, ${ }^{172}$ which the applicant may self-administer or that the practitioner may administer. ${ }^{173}$ If the applicant is physically unable to sign the formal request form, a proxy may sign the request for MAID in the presence of the person making the request, on that person's behalf and under their express direction. ${ }^{174}$ As a safeguard, the proxy must satisfy a number of criteria to ensure the applicant is not being pressured. ${ }^{175}$ Regardless of whether the applicant or a proxy signs the request, the request must be signed in the presence of two independent witnesses. ${ }^{176}$

Ibid, s 241.2(1)(b).

Ibid, ss 241.2(1)(c), 241.2(2) [emphasis added].

Ibid, s $241.2(1)(\mathrm{d})$.

Ibid, s 241.2(1)(e).

The pharmacist involved must be informed when a prescription is being prescribed or obtained for the purpose of delivering MAID (ibid, s 241.2(8)).

Health Canada, "Medical Assistance in Dying," online: <https://www.canada.ca/en/health-canada/ services/medical-assistance-dying.html>.

Criminal Code, supra note 10, s 241.2(4). An alternate decision-maker cannot make a request for or consent to MAID on behalf of an applicant who lacks capacity.

For instance, the proxy must be 18 years of age, understand the nature of the request for MAID, and must not know or believe they are a beneficiary under the will of the patient making the request or a recipient in any other way of a financial or material benefit resulting from the patient's death (ibid). Criminal Code, supra note 10, ss 241.2(3)(c), 241.2(5). The witnesses cannot know or believe that they are a beneficiary under the will of the applicant, or a recipient in any other way of a financial or other material benefit arising from that applicant's death; be an owner or operator of any health care facility at which the applicant is being treated or any facility in which that applicant resides; be directly involved in providing health care services to the applicant; or directly provide personal care to the applicant. 


\section{Second Stage: Assessments for Eligibility}

Following a formal request for MAID, two mandatory eligibility assessments must be carried out by two independent practitioners, the first of which can be the applicant's family physician. ${ }^{177}$ Once satisfied that all requirements have been met, the two practitioners must provide written confirmations that the applicant meets the statutory requirements, with particular attention to the criteria of "grievous and irremediable" condition. ${ }^{178}$ For example, when confirming statutory requirements the practitioner could state for a patient suffering from cancer that "the patient has a known advanced aggressive colon cancer with increased abdominal mass in the left lower quadrant, anorexia, weight loss, and abdominal pain. The patient has no interest in palliative care and wishes to engage MAID."

Once a practitioner is satisfied that all criteria has been met, they will approve the request in writing. ${ }^{179}$ The practitioner who will provide MAID will discuss and agree on a plan with the applicant regarding when, where, and how MAID will be provided, including the administering practitioner's presence and any additional support necessary. ${ }^{180}$ An alternative plan to address potential complications should be discussed. ${ }^{181}$ The applicant can decide the location to engage MAID, whether that is at a hospice, long-term care facility, their home, or some other place where they are an inpatient. ${ }^{182}$ The applicant can also decide whether

Ibid, ss 241.2(3)(e)-(f). Physicians and nurse practitioners are independent if they are not in a mentorship or supervisory relationship with each other, do not know or believe that they are a beneficiary under the will of the applicant making the request, or a recipient, in any other way, of a financial or other material benefit resulting from that patient's death, other than standard compensation for their services relating to the request, and do not know or believe that they are connected to the other physician or nurse practitioner or to the applicant making the request in any other way that would affect their objectivity.

See e.g. Alberta Health Services, "Comprehensive Clinical Guide for Medical Assistance in Dying for Physicians and Nurse Practitioners" (Edmonton: AHS, 2017) at 14 [AHS, "Comprehensive Clinical Guide"]; Alberta Health Services, "Providing Practitioner Record for Medical Assistance in Dying" (2 August 2017), online: Forms < $<$ www.albertahealthservices.ca/info/Page14381.aspx $>$ [AHS, "Providing Practitioner Record"].

Provinces and territories have developed their own written forms to assist physicians and nurse practitioners in maintaining appropriate records for MAID: see e.g. AHS, "Providing Practitioner Record," ibid; Ontario, Ministry of Health and Long-Term Care, "Medical Assistance in Dying," online: $<$ www.health.gov.on.ca/en/pro/programs/maid/>; British Columbia, Ministry of Health, "Forms for Medical Assistance in Dying," online: < https://www2.gov.bc.ca/gov/content/health/accessing-healthcare/home-community-care/care-options-and-cost/end-of-life-care/medical-assistance-in-dying/forms > . See Alberta Health Services, "Medical Assistance in Dying: Eligibility and Planning," online: <www. albertahealthservices.ca/assets/info/hp/maid/if-hp-maid-eligibility-and-planning.pdf >; AHS, "Comprehensive Clinical Guide," supra note 178 at 12.

181 AHS, "Comprehensive Clinical Guide," ibid at 12. For instance, where individuals choose the selfadministered protocol, there should be a discussion as to whether the applicant consents to convert to the practitioner-administered protocol in case of complications.

182 If an applicant is being cared for at a non-participating or faith-based institution, they may have to be transferred to a participating site before proceeding further. For instance, this situation may arise where a physician or nurse practitioner denies taking part in the MAID process because it violates their moral conscience. Conscientious objection is allowed under the legislative scheme: see Criminal Code, supra note 10, s 241.2(9); Carter SCC, supra note 1 at paras 130-32; End-of-Life Care Act, supra note 21, ss 31, 50; Peter G Brindley \& Jeff P Kerrie, "Conscientious Objection and Medical Assistance in Dying (MAID) in Canada: Difficult Questions - Insufficient Answers" (2016) 11:4 Can J General Internal Medicine 7. See also The Christian Medical and Dental Society of Canada v College of Physicians and Surgeons of Ontario, 2018 ONSC 579, 2018 ONSC 579 (CanLII) at para 1 where "the applicants challenged the constitutional validity of two policies of the College of Physicians and Surgeons of Ontario that require physicians who are unwilling to provide elements of care on moral or religious grounds to provide requesting such care with an effective referral to another health care provider." The Court held that while the provisions infringed section 2(a) of the Charter, they were ultimately saved by section 1 . 
they wish to have family and friends present at the time of engaging MAID. The applicant may withdraw their formal request at any time during this process. ${ }^{183}$

\section{Final Stage: Engaging MAID ${ }^{184}$}

After ten days have passed following the day on which the request was originally signed, ${ }^{185}$ MAID may be provided to the applicant. Immediately prior to administration of the substance causing the applicant's death, the providing practitioner must give the patient an opportunity to withdraw their request and the physician must satisfy themselves that the patient gave express, informed, and voluntary consent to engage MAID. ${ }^{186}$

Once the applicant has died, physicians and nurse practitioners have a variety of obligations. ${ }^{187}$ For instance, depending on the jurisdiction in which they are practicing, they may have to notify the coroner or medical examiner. ${ }^{188}$

Any physician or nurse practitioner who does not comply with the safeguards outlined ${ }^{189}$ is guilty of an offence and liable to not more than five years' imprisonment on conviction on indictment, or 18 months imprisonment on summary conviction. ${ }^{190}$ Therefore, it is wise for a practitioner to connect with their regulatory colleges and review standards of practice, or the Canadian Medical Protective Association or Canadian Nursing Protective Society for specific legal guidance.

\section{THE JOURNEY FORWARD}

While it is beyond the scope of this article to critically analyze or resolve the following concerns on their merits, this section will provide an overview of concerns that have arisen since new legislation was implemented.

Criminal Code, ibid, s 241.2(3)(d).

"Engage MAID" is a term used by the authors to describe the moment where MAID is carried out (that is, the act of actually administering the substance causing death).

This is referred to as a "period of reflection" that allows the applicant to think about their decision. They are able to withdraw their formal request at any time before the substance causing their death is administered. An abridgment of time may be permitted if the person's death or loss of capacity is imminent (Criminal Code, supra note 10, s 241.2(3)(g)).

If the patient has difficulty communicating, all necessary measures shall be taken to provide information in a manner the patient will understand the information and communicate their decision (ibid, s 241.2(3)(i)).

Requirements following the applicant's death will vary between jurisdictions, and physicians and nurse practitioners should connect with their regulatory colleges or the Canadian Medical Protective Association for legal guidance. For an example of practitioner requirements following death (such as reporting, post-event arrangements, completion of death certificate, and other required documentation), see AHS, "Comprehensive Clinical Guide," supra note 178 at 16-17.

188 For instance, in British Columbia, the prescribing practitioner is responsible for submitting all provincial forms for MAID to the BC Coroner's Service: see British Columbia Ministry of Health, "Medical Assistance in Dying," online: $<$ https://www2.gov.bc.ca/gov/content/health/accessing-health-care/homecommunity-care/care-options-and-cost/end-of-life-care/medical-assistance-in-dying/information-forproviders>; Vital Statistics Act, RSBC 1996, c 479, s 18. Under Ontario law, providing physicians and nurse practitioners are required to notify the coroner: see Ontario, Ministry of Health and Long-Term Care, supra note 179.

For a complete list of safeguards, see Criminal Code, supra note 10, s 241.2(3).

Ibid, s 241.3. If practitioners have a reasonable but mistaken belief about some relevant fact, they have a "good faith" defence available to them: see Department of Justice, "Legislative Background: Medical Assistance in Dying (Bill C-14)," online: <www.justice.gc.ca/eng/rp-pr/other-autre/ad-am/p2.html> [Department of Justice, "Legislative Background]; Criminal Code, ibid, s 227(3). 


\section{A. Issues OF Constitutionality}

Concerns over the constitutionality of the new legislation were originally expressed in testimony before the Standing Senate Committee on Legal and Constitutional Affairs during their consideration of Bill C-14. Peter Hogg, one of Canada's leading constitutional law experts, submitted, "[i]n my opinion, the Bill is not consistent with the constitutional parameters set out in the Carter decision" for the following reasons:

It is clear from these two decisions [EF and $I J]$, that the class of persons entitled to the Charter right of physician-assisted death includes people whose suffering is not an end-of-life condition. But, if Bill C-14 were enacted in its present form, the class of entitled persons would no longer include people whose suffering is not an end-of-life condition.

If Bill C-14 is enacted in its present form, it can safely be predicted that a member of the newly excluded class - those who satisfy the Carter criteria and do not have an end-of-life condition — will bring a constitutional challenge to the new legislation. The challenge will come before a single judge and the challenger will show the judge three things: (1) the order made by the Supreme Court in Carter, (2) the two decisions confirming that Carter did not require any end-of-life conditions, and (3) sections 241.2(2)(b) and (d) of Bill C-14. What judge would not strike down the end-of-life provisions? ${ }^{191}$

Given the decisions in $E F$ and $I J$, as discussed above, as well as Hogg's submission, it is not unlikely that a court would be willing to revisit the constitutionality of the law.

Indeed, in June 2016, Julia Lamb commenced an action with the British Columbia Civil Liberties Association in the British Columbia Supreme Court against the Attorney General of Canada, challenging portions of section 241.2(2). ${ }^{192}$ Specifically, they take issue with the definition of "grievous and irremediable" in section 241.2(2), which includes the phrases "incurable" in 241.2(2)(a), "advanced state" in section 241.2(2)(b), and "reasonably foreseeable" death in section $241.2(2)(d) .{ }^{193}$ Lamb has spinal muscular atrophy type 2, a hereditary disease that causes weaknesses and wasting of the voluntary muscles. ${ }^{194}$ The claimants argue that Canadians suffering from diseases such as spinal muscular atrophy, multiple sclerosis, spinal stenosis, locked-in syndrome, traumatic spinal injury, Parkinson's disease, and Huntington's disease, among others, will not be eligible for MAID under the new law. ${ }^{195}$ Thus, the claimants argue that the right to life, liberty, and security of the person are engaged for reasons similar to those in Carter. ${ }^{196}$ Furthermore, the claimants argue that the new legislative scheme violates section 15 of the Charter in that it has adverse effects on

Peter W Hogg, "Presentation to Standing Senate Committee on Legal and Constitutional Affairs Bill C14 (Medical Assistance in Dying)" (Presentation, 6 June 2016) at 1-2, online: $<$ https://sencanada.ca/ content/sen/committee/421/LCJC/Briefs/LCJC_June_6_2016_SN_Hogg_e.pdf> [unpublished]. Lamb v Canada (Attorney General) (27 June 20̄16), V̄ancouver, BCSC (Notice of Civil Claim). Ibid at 3; Criminal Code, supra note 10, ss 241.2(2)(a)-(b), (d).

Supra note 192 at 3-4.

British Columbia Civil Liberties Association, "Lamb v Canada: The Death With Dignity Case Continues," online: < https://bccla.org/our-work/blog/lamb/>.

196 See Firuz Rahimi, "Assisted Death in Canada: An Exploration of the Constitutionality of Bill C-14" (2017) 80:2 Sask L Rev 457 at 464. 
people like Lamb, in that it indirectly excludes some individuals. ${ }^{197}$ Lamb wants the peace of mind knowing that individuals who find options to treat a "curable" illness intolerable may seek MAID to alleviate their suffering, provided they are fully informed and clearly consenting to it, and the condition has brought them to the point of enduring and intolerable suffering.

\section{B. ISSUES OF CERTAinTy}

Issues of certainty have also arisen with physicians struggling to determine whether the applicant's natural death is "reasonably foreseeable, taking into account all of their medical circumstances." 198 The legislation expressly states that death must be "reasonably foreseeable, taking into account all of their medical circumstances," ${ }^{199}$ which, according to the federal government, "could include considerations of age or frailty, and the interaction of several different medical conditions which may cause the person to be in a life-threatening condition. ${ }^{200}$ As such, despite concerns that Carter would not have been eligible for MAID under the legislative requirements, ${ }^{201}$ the federal government maintains that her natural death had become reasonably foreseeable taking into account her medical circumstances. ${ }^{202}$

The federal government's explanation has not provided much certainty as to when an applicant's death is "reasonably foreseeable." In A.B., disagreement between physicians over whether A.B.'s natural death was "reasonably foreseeable" led to no physician being prepared to offer MAID. ${ }^{203}$ A.B., an almost 80-year-old woman suffering from incurable and erosive osteoarthritis, applied for a declaration to protect the physicians from criminal charges. ${ }^{204}$ Justice Perell interpreted and explained section 241.2(2)(d) of the Code, quoting the Federal Minister of Justice and Attorney General of Canada:

To be clear, the bill does not require that people be dying from a fatal illness or disease or be terminally ill.

Rather, it uses more flexible wording; namely, that "their natural death has become reasonably foreseeable, taking into account all of their medical circumstances".... It makes sense to limit medical assistance in dying to situations where death is reasonably foreseeable, where our physicians, nurse practitioners, and others, can draw on existing ethical and practical knowledge, training and expertise in addressing those challenging circumstances. $^{205}$

Ibid at 469. See also Lamb v Canada (Attorney General), 2017 BCSC 1802, 5 BCLR (6th) 175, where the British Columbia Supreme Court denied the applicant's request to prevent the federal government from reintroducing evidence on issues that had already been decided in Carter.

Criminal Code, supra note 10, s 241.2(2)(d). See Kelly Grant, "Group of Assisted-Death Providers Publish Clinical-Practice Guideline," The Globe and Mail (2 June 2017), online: <https://www.theglobe andmail.com/news/national/group-of-assisted-death-providers-publish-clinical-practiceguideline/article35192103/>.

Criminal Code, ibid.

Department of Justice, "Questions and Answers," supra note 20.

See House of Commons Debates, 42nd Parl, 1st Sess, No 46 (2 May 2016) at 2730 (John Aldag); Mike Laanela, "Nix or Amend Right to Die Bill, Says Family of Kay Carter," CBC News (6 June 2016), online: <www.cbc.ca/news/canada/british-columbia/kay-carter-assisted-dying-1.3618100>.

Department of Justice, "Questions and Answers," supra note 20.

$A B$, supra note 140 at paras $1-2$.

Ibid at paras 2, 31 .

Ibid at para 43 [emphasis added]. 
Justice Perell then made a declaration of statutory interpretation of the meaning of "natural death has become reasonably foreseeable" in s 241.2(2)(d), stating:

[T] hose words are modified by the phrase "taking into account all of their medical circumstances, without a prognosis necessarily having been made as to the specific length of time that they have remaining." This language reveals that natural death need not be imminent and that what is a reasonably foreseeable death is a person-specific medical question. ${ }^{206}$

In order to provide some clarity over what constitutes "foreseeable," the Canadian Association of MAID Assessors and Providers released clinical guidelines on how medical providers should apply the legislation. ${ }^{207}$

\section{ISSUES OF CAPACITY}

In Carter, Justice Rothstein allowed Canada to file fresh evidence on developments in Belgium since the time of trial; specifically, this included affidavit evidence reviewing a number of controversial cases relating to minors or those suffering from psychiatric disorders. ${ }^{208}$ The Supreme Court of Canada was not convinced that this evidence undermined Justice Smith's reasons, as they offered little insight into how a Canadian regime might operate. ${ }^{209}$ In doing this, the Supreme Court of Canada ensured the parameters of their decision were confined to the facts at hand; in other words, they "[made] no pronouncement on other situations where physician-assisted dying may be sought." 210 That is, the Supreme Court of Canada in Carter set a floor and not a ceiling, and the issues of mature minors, mental illness, and advance directives that were not before the Supreme Court were remitted to Parliament in a show of legislative deference.

Parliament determined that a person must be mentally capable of giving informed consent to engage MAID. They must understand and appreciate their diagnosis, prognosis, and available treatments, including possible side effects and benefits ${ }^{211}$ up to, and including, the moment immediately prior to MAID being provided. ${ }^{212}$ The preamble to Bill C-14 indicates that restricting access to MAID in this manner "strikes the most appropriate balance between the autonomy of persons who seek [MAID], on one hand, and the interests of vulnerable persons in need of protection and those of society, on the other." 213

As per clause 9.1(1) of Bill C-14, the Federal Ministers of Justice and Health, no later than 180 days after the day on which the new federal legislation received royal assent, were to initiate one or more independent reviews of issues relating to requests by mature minors for MAID, to advance directives, and to mental illness. ${ }^{214}$ In December 2016, the federal government announced these reviews will be conducted by an Expert Panel appointed by the

Ibid at para 79.

Canadian Association of MAID Assessors and Providers, "The Clinical Interpretation of "Reasonably Foreseeable" (June 2017), online: <www.camapcanada.ca/cpg1.pdf>.

Carter SCC, supra note 1 at paras $110-11$.

Ibid at paras $112-13$.

Ibid at para 127.

See Philip H Osborne, The Law of Torts, 4th ed (Toronto: Irwin Law, 2011) at 149-51.

Criminal Code, supra note 10, s 241.2(3)(h).

Bill C-14, supra note 19, Preamble.

Ibid, s $9.1(1)$. 
Council of Canadian Academies (CCA), an independent organization that undertakes evidence-based, expert assessments to support and inform public policy development in Canada. ${ }^{215}$ The Expert Panel on MAID held its first meeting in May 2017. Over the coming months, it is expected the Panel will guide the CCA staff in the evidence-gathering process, examine available evidence, and seek input on evidence from various organizations, medical professionals, and other stakeholders. ${ }^{216}$ The following question will guide the work:

What is the available evidence on, and how does it inform our understanding of, medical assistance in dying (MAID) in the case of mature minors, advance requests, and where mental illness is the sole underlying medical condition, given the clinical, legal, cultural, ethical, and historical context in Canada? ${ }^{217}$

It remains to be seen what guidance the Expert Panel on MAID will offer the Federal Minister of Health and the Justice Minister and Attorney General of Canada when it concludes examinations of this question. It is expected that three separate reports will be finalized and released publicly by late $2018 .^{218}$ Until then, the only option available to those Canadians excluded under the legislation is to seek the assistance of the courts. ${ }^{219}$

\section{Ensuring EfFective Monitoring}

As recognized by the Supreme Court in Carter, ${ }^{220}$ and by the Special Joint Committee's report, ${ }^{221}$ a pan-Canadian data collection and monitoring system established to monitor trends and provide information to the public is a critical component of the new legislative regime. Bill C-14 proposed to create a power for the Federal Minister of Health to make regulations establishing such a monitoring system. ${ }^{222}$ No federal regulations have come into force; ${ }^{223}$

Health Canada, "Medical Assistance in Dying," online: <https://www.canada.ca/en/health-canada/ services/medical-assistance-dying.html $>$.

Council of Canadian Academies, "Medical Assistance in Dying," online: <www.scienceadvice.ca/ en/assessments/in-progress/medical-assistance-dying.aspx>.

Ibid.

Ibid.

For further literature on these topics, see: Juliet Guichon et al, "Autonomy and Beneficence in Assisted Dying in Canada: The Eligibility of Mature Minors" (2017) 54:3 Alta L Rev 775; Kathleen Sheehan, K Sonu Gaind \& James Downar, "Medical Assistance in Dying: Special Issues for Patients with Mental Illness" (2017) 30:1 Current Opinion Psychiatry 26; Skye Rosseau et al, "A National Survey of Canadian Psychiatrists' Attitudes Toward Medical Assistance in Death" (2017) Can J Psychiatry 787; Paul T Menzel \& Bonnie Steinbock, "Advance Directives, Dementia, and Physician-Assisted Death" (2013) 41:2 JL Med \& Ethics 484.

Carter SCC, supra note 1 at para 117.

Special Joint Committee on Physician-Assisted Dying, supra note 21 at 31-32.

Criminal Code, supra note 10, s 241.31(3). To be clear, the authors are not suggesting the federal government has the authority to impose a registry, as this would exceed their legislative authority under the Constitution Act, 1867 (UK), 30 \& 31 Vict, c 3, reprinted in RSC 1985, Appendix II, No 5: see Reference re Assisted Human Reproduction Act, 2010 SCC 61, [2010] 3 SCR 457, where the Supreme Court of Canada struck down the federal government's conceived donor registry. Due to the practical implication of the division of powers in Canada, whereby the federal government may develop appropriate eligibility criteria and safeguards while provinces and territories are responsible for specific policies pertaining to administration of health services, provinces and territories have been tasked with monitoring MAID: see Special Joint Committee on Physician-Assisted Dying, supra note 21 at 4-6. Nonetheless, the Canadian cancer registry system exemplifies how provinces and territories can create their own MAID registry, which could then link up with Statistics Canada: see e.g. Barbara von Tigerstrom \& Nola M Ries, "Cancer Surveillance in Canada: Analysis of Legal and Policy Frameworks and Tools for Reform" (2009) 17 Health LJ 1.

British Columbia, Ontario, and Quebec remain the only provinces with provincial legislation pertaining to the monitoring and reporting of MAID. In the British Columbia Coroners Regulation, BC Reg 298/2007, s 1.1, British Columbia has mandated that a medical practitioner must notify the coroner of the death if the person's death resulted from MAID. In Ontario, Bill 84, An Act to amend various Acts with respect to medical assistance in dying, 2nd Sess, 41st Leg, Ontario, 2017 (assented to 10 May 
however, they are being developed in order to establish a comprehensive monitoring regime. ${ }^{224}$ These regulations may allow for collection of data and information relating to MAID including: (1) information provided by medical or nurse practitioners; (2) the form, manner, and circumstances in which information has been provided; (3) details about how data would be analyzed and reported to the public; and (4) rules for protection and dispersal of such information. ${ }^{225}$ To ensure an effective operation, the proposed legislation would also create a legal obligation for medical and nurse practitioners receiving a written request for MAID to provide information required by the regulations. ${ }^{226}$ Failure to comply with this legal obligation would be punishable by a maximum penalty of two years imprisonment, proceeding either by summary conviction or by an indictment. ${ }^{227}$ These reporting obligations and related offences would be brought into force at a later date than the rest of Bill C-14, once regulations on the monitoring regime are in place. ${ }^{228}$

Monitoring and reporting encourages transparency as well as public accountability, and aids Canadian citizens, including politicians, in evaluating whether the legislative approach is achieving the goal of respecting autonomy for eligible individuals, while at the same time protecting vulnerable persons and the conscientious objection of some health care providers. ${ }^{229}$ Unfortunately, publicly available government data on MAID practices has been limited. ${ }^{230}$ Creation of separate databases related to MAID cases, MAID applicants deemed to not qualify at the time of application, and applicants who die prior to the final steps is considered by the federal government to be critical to a greater understanding of the new legal practice by society. The process that starts when interest is expressed by those wishing

2017), SO 2017, c 7, received Royal Assent on 10 May 2017. The legislation amends the Coroners Act, RSO 1990 , c C.37, to provide that the physician or nurse practitioner that provided MAID shall notify the coroner and provide the coroner with any information necessary to determine whether to investigate the death, and other people with knowledge of the death shall provide the coroner with information on request (Coroners Act, ibid, s 10.1). Quebec's End-of-Life Care Act, supra note 21, s 8 mandates that the executive director of all institutions must adopt a policy with respect to end-of-life care and report annually to their board of directors on the number of requests for MAID and the number of times MAID was administered or not administered (and the reasons for or against). Quebec's legislation also instituted the Commission sur les soins de fin de vie, which reviews issues relating to end-of-life care and monitors MAID practices (ibid, ss 38,42 ).

Health Canada, "Forward Regulatory Plan: 2017-2019," online: <https://www.canada.ca/en/healthcanada/corporate/about-health-canada/legislation-guidelines/acts-regulations/forward-regulatoryplan/2016-2018.html>. Draft regulations were recently released by the federal government for the ultimate purpose of creating a pan-Canadian monitoring system on MAID. See supra note 173.

Bill C-14, supra note $19, \mathrm{~s} 4$.

Ibid. This legal obligation would include pharmacists.

Ibid.

Department of Justice, “Legislative Background,” supra note 190.

Department of Justice, "Questions and Answers," supra note 20.

The federal government has released two interim reports covering the first twelve months during which MAID has been available in Canada (17 June to 30 June 2017: Health Canada, "Interim Update on Medical Assistance in Dying in Canada June 17 to December 31, 2016," online: <https:/www.canada. $\mathrm{ca} / \mathrm{en} /$ health-canada/services/publications/health-system-services/medical-assistance-dying-interimreport-dec-2016.html>; Health Canada, "2nd Interim Report on Medical Assistance in Dying in Canada," online: $<$ https://www.canada.ca/en/health-canada/services/publications/health-system-services/ medical-assistance-dying-interim-report-sep-2017.html $>$ ). While the scope of data currently available is relatively limited, Health Canada was able to collect data on the following from most provinces and territories: aggregate number of medically assisted deaths; basic demographic information on persons receiving assisted dying; most common circumstances, illnesses, diseases, or disabilities of persons receiving assisted dying; and the setting in which medical assistance in dying occurred. Alberta remains the only Canadian jurisdiction that has released weekly updates to the public on cumulative provincial and zone data. The data released by Alberta thus far has included: (1) average age of patients; (2) number of people who did not meet federal mandatory eligibility criteria; (3) number of patients transferred from a non-AHS facility; and (4) most cited health conditions. For up-to-date information, see Alberta Health Services, "Data and Stats," online: <www.albertahealthservices.ca/info/Page 14930.aspx>. 
to access MAID needs to be documented so that participants at all levels — patients, physicians, pharmacists, lawyers, medical examiners, and society - can be made aware of what people throughout Canada are experiencing.

Collected information can help to identify and minimize coercive behaviour or negligence by medical professionals, identify regions where access to MAID is limited, ${ }^{231}$ monitor whether certain requirements or safeguards are subject to variability or non-compliance, and assist studies that would share useful information while respecting the right to privacy. Evidence from other jurisdictions' experience with assisted dying indicates that one challenge is ensuring that cases are being reported. In the Netherlands the reporting rate is significantly higher ( 80 percent) than in Belgium ( 53 percent). ${ }^{232}$ The primary reasons for non-reporting appear to be differences in labelling and awareness of reporting obligations. ${ }^{233}$ This underscores the need for all levels of Canadian government to work together to identify and agree on identical data collection variables and definitions in an effort to collect adequate data.

\section{CONCLuSion}

We have come a long way from the time where the Law Reform Commission of Canada wrote that "[a] country like Canada could not, without violating its social traditions and history, tolerate and give a legal veneer to [this] policy." ${ }^{, 34}$ By 2016, a major shift in social mores and norms culminated in the setting aside of a prohibitive criminal law and the development of a permissive regime. Canadians, with certain exceptions as dictated by legislation, can now alleviate their suffering, mentally and physically, while awaiting their "natural" death. Yet, this is far from the final chapter; while the criminal law establishes the general rules of conduct of what society permits, it cannot alone provide a comprehensive clinical guide for decision-making. Accordingly, the new legislation is part of the ongoing dialogue between multiple participants, including physicians, nurses, pharmacists, lawyers, politicians, and the greater public. Over time, the new MAID regime will evolve, cases will vary, and individual assessments and subjective decisions will have to be made. For all Canadians, but especially those currently precluded from seeking MAID, the journey continues.

See Nicole Ireland, "One Year After Canada's Medically Assisted Dying Law, Patients Face Uneven Access," CBCNews (18 June 2017), online: $<$ www.cbc.ca/news/health/medically-assisted-dying-accessone-year-later-1.4165936>. Penney Lewis \& Isra Black, The Effectiveness of Legal Safeguards in Jurisdictions That Allow Assisted Dying (London: Demos, 2012) at 69. 
[this page is intentionally blank] 